\title{
GOVERNING GURU
}

\author{
The Political Economy of Teacher Distribution in Indonesia ${ }^{1}$
}

\author{
ANDREW ROSSER
}

Indonesia has an abundance of teachers — around 3 million by one estimate (The Economist, 2014) — giving it one of the most enviable teacher-student ratios in the world (USAID Prioritas, 2015). But these teachers are poorly distributed between schools, and especially between schools in urban areas and rural and remote areas. As AlSamarrai et al (2012: 2) have explained, this maldistribution has involved not simply unevenness in the supply of teachers but also in their quality: '[M]ore qualified and experienced teachers are frequently concentrated in wealthier urban areas'. As one measure of the scale of the problem, USAID (2015) found that teacher-student ratios in a set of 23 districts and municipalities ranged from 10 in urban Madiun to 25 in the remote rural district of Nias Selatan. There is also a marked maldistribution of teachers within districts and municipalities, with the urban-rural divide again being the central dimension of inequality (Al-Samarrai et al, 2012; Heyward et al, 2017: 252). Al-Samarrai et al (2012) illustrate that the Indonesian government's standards on teacher numbers at the school level could be largely met by redistributing teachers more equitably within these districts/municipalities.

This maldistribution of teachers is widely considered to have undermined the country's performance in promoting learning. For instance, in a recent study, the World Bank (2013: 80) found that teacher maldistribution had contributed to diminished educational performance in Bahasa Indonesia amongst students in rural and remote areas compared to students in urban areas. More generally, Indonesia has consistently achieved dismal results in international standardized tests such as the Program for International Student Assessment (PISA) and Trends in International Mathematics and Science Study (TIMSS) since it started participating in these tests in the late 1990s. ${ }^{2}$ Indonesia's central government has introduced a range of reform initiatives in recent years to address teacher maldistribution but these have had little effect. Recent government statements and media reports suggest that the problem remains largely unsolved (e.g. Warta Ekonomi, 2018).

What explains the maldistribution of teachers in Indonesia? Most analysis of teacher distribution in developing countries has focused on mapping the distribution of teachers within countries, identifying areas of over- and under-supply, assessing the effects on learning outcomes and government budgets, and devising programs for redistributing teachers (Mulkeen, 2010 and Al-Samarrai et al, 2012). It has given relatively little attention to the underlying causes of teacher maldistribution and, in particular, the role of politico-economic factors in this respect. ${ }^{3}$

This paper focuses on precisely these factors. It suggests that teacher maldistribution in Indonesia has its origins in the way in which predatory political and bureaucratic elites, at both the national and local levels, have for decades used the school system - and teacher management in particular - to accumulate resources, distribute patronage, mobilize political support, and exercise political control. This orientation has meant that teacher numbers, quality, and distribution have been managed to maximize flows of rents and votes from schools to these elites, lubricate patronage and political networks, and ensure that these elites maintain political control rather than to maximize educational performance and equity, notwithstanding their rhetoric in support of the latter. Democratization and decentralization since the fall of the New Order, the authoritarian and centralized regime that ruled Indonesia from 1965 to 1998 , have done little to change this situation. They have consolidated the formal authority of district governments in relation to teacher management and created genuine competition within the local elite for teachers' votes. But schools' role as a source of rents and votes and a mechanism for distributing patronage and exercising political control has remained more or less unchanged.

In this context, central government initiatives to promote a more equitable distribution of teachers have represented a direct assault on elite interests. In particular, given that local elites play the dominant role in teacher management, the central government's efforts have represented an assault on the interests of local elites. Central

\footnotetext{
${ }^{1}$ The research on which this paper is based was funded by Australia's Department of Foreign Affairs and Trade and the World Bank. An earlier version of the paper was initially published in working paper form as part of Andrew Rosser and M. Fahmi (2016) The Political Economy of Teacher Management in Decentralised Indonesia, World Bank Policy Research Working Paper, 7913. The usual caveat applies. ${ }^{2}$ On these results, see Pisani (2013).

${ }^{3}$ A notable exception is Heyward et al (2017).
} 
government reform initiatives have consequently encountered considerable - if often subterranean-resistance except in a few exceptional cases where specific conditions conducive to reform have emerged. The paper argues - on the basis of an analysis of the political dynamics surrounding teacher distribution in four regional cases - that these conditions are: i) where mid-level government officials, especially officials in the local education agency, judge that reform initiatives can be exploited for patronage purposes; secure support from more senior officials; and they devise effective strategies for managing the politics of reform; ii) where reform-minded district leaders are elected providing an imperative for education agency officials to design reform programs and the latter have access to relevant ideas and policy advice as a result of contact with donors; and iii) the central government devises and implements policy instruments that, accidently or otherwise, provide regional governments with firm incentives to carry out teacher redistribution.

In presenting this argument, the paper begins by providing a general overview of the political economy of teacher management in Indonesia. It then examines the experiences of four districts with regards to teacher redistribution in an attempt to understand both the political obstacles to this policy and the conditions under which, to the extent teacher redistribution has occurred, it has been possible. The final section of the paper draws out the policy implications of the analysis.

\section{THE POLITICAL ECONOMY OF TEACHER MANAGEMENT ${ }^{4}$}

The New Order invested heavily in promoting improved access to education, especially basic education. It dramatically expanded the scope of the public school system, especially during the oil boom years of the 1970s and early 1980s when the government was awash in petrodollars, achieving universal primary enrolment in the early 1980s (Prawiro, 1998: 180). However, corruption undermined the educational effectiveness of this investment. Indonesian schools became part of the larger 'franchise' structure that characterized the New Order's rule, the key feature of which was the purchase of government positions in exchange for access to the rents they could generate (McLeod, 2000). As such, teachers became incorporated into networks of corruption and patronage as both generators and beneficiaries of the rents that education budgets and teaching positions made available (Irawan et al, 2004: 50; Rosser and Joshi, 2013).

At the same time, the New Order used schools as vehicles for mobilizing votes at election time and exercising political control (Schiller, 1999: 11; Bjork, 2003: 192-193). The school system was one of few national institutional structures that reached all the way down to the village level, making it an extremely important link between the predatory political and bureaucratic elites who dominated the New Order and the masses. As civil servants, teachers were required to support Golkar, the New Order's electoral vehicle; display 'mono-loyalty' to the state; and both take and teach compulsory courses in the state ideology, Pancasila. If they failed to perform these responsibilities, they risked demotion or transfer to less attractive schools, particularly in remote areas. Teachers were also required to be members of the Indonesian Teachers Union (PGRI), the sole recognized teachers' trade union. Established in 1945 as part of the nationalist resistance to Dutch rule, the PGRI operated during the New Order period as a mechanism for controlling teachers rather than the articulation of their collective interests. Its political subordination was made transparent by its incorporation into Golkar in 1970 (Kompas, 1970). In exchange for its allegiance to the New Order, the PGRI was given a monopoly on the representation of teachers and the authority to extract fees from teachers' salaries with little or no accountability over use of the associated funds (Reeve, 1985: 328).

In this context, there was little political will within the government to address issues related to teacher quality, teacher distribution, or teacher numbers and cost. Rather the dominant logic at work was to expand and consolidate networks of corruption and patronage and enhance political control. This meant maximizing teacher numbers to provide additional patronage opportunities while expecting little of teachers in terms of accountability for educational outcomes. One consequence was maldistribution of teachers as political and bureaucratic elites ensured that their friends, family and political allies gained teaching positions at schools in urban areas near their family and social networks. Particularly privileged in this respect were the 'favourite schools' attended by children of local government officials and other members of the middle class.

The Asian economic crisis in 1997 and demise of the New Order regime in 1998 produced a political context that was slightly more conducive to teacher management reform and teacher redistribution in particular. The crisis undermined the economic base of predatory New Order elites and their corporate clients and forced the government to negotiate a rescue package with the International Monetary Fund (IMF) and accept increased aid.

${ }^{4}$ This section draws heavily on Rosser and Fahmi (2018). 
In this context, government technocrats, particularly in the National Development Planning Agency (Bappenas) and the Ministry of Education and Culture (MoEC), pushed hard for teacher management reform, leveraging the support of the World Bank and other members of the donor community. In September 1998, the Bank published a major report on Indonesia's education system which argued that: 'A key part of quality improvement is teachers - having them equitably distributed, giving them appropriate incentives, and ensuring they are adequately trained' (World Bank, 1998: x). Immediately afterward, it then co-funded with Bappenas the establishment of a series of Task Forces to prepare reports on key education policy issues including teacher management (Jalal and Musthafa, 2001). Over the next few years, donors provided loans and grants to the Indonesian government for a series of projects related to teacher management including USAID's Kinerja and Prioritas projects, both of which had an explicit concern with teacher distribution.

In seeking to promote teacher management reform, however, government technocrats and their allies in the donor community were constrained by three factors. The first was the fact that they had little direct authority over the implementation of teacher management policy. Under the New Order, district and municipal governments already had primary responsibility for implementing teacher management policy notwithstanding the centralized nature of New Order rule (King, 1995: 80-84). The introduction of new decentralization laws in 1999 and their implementation in 2001 consolidated the role of these governments in this respect by granting them formal authority over education policy. The second constraint was the continued political dominance during the postNew Order period of predatory military and bureaucratic officials and their corporate clients; at both national and regional levels, long-standing patronage and political networks have consequently remained an entrenched feature of Indonesia's system of education governance. The third constraint was the fact that democratization opened up new opportunities for teachers to challenge teacher management reform by allowing the PGRI greater autonomy from government, enabling the establishment of new teacher organisations, and creating greater scope for these organisations to lobby policy-makers and use courts to achieve their ends.

The overall effect of this political context was to severely limit the extent to which technocratic elements and their donor supporters were able to promote teacher management reform including teacher redistribution. For instance, in an attempt to promote teacher redistribution, the central government's Education Committee chaired by VicePresident Boediono, a former economics professor and a prominent technocrat, agreed that five government ministers (the Minister of National Education, the State Minister for the Empowerment of the State Apparatus and Bureaucratic Reform, the Minister of the Interior, the Minister of Finance, and the Minister of Religious Affairs), all of whom were represented on the Committee, should issue a joint regulation instructing regional (and especially district/municipal) governments ${ }^{5}$ to redistribute teachers more equitably (Kompas, 2010). Issued in 2011, the Five Ministerial Decree, as the regulation has become known, threatened regional governments with a range of sanctions if they did not comply. These included the withdrawal, in part or full, of education funding to regional governments; delays in the granting of new civil service teacher positions to regional governments; and delays in the provision of 'balancing funds' (dana perimbangan) to regional governments.

This regulation has had little effect at the regional level: as various commentators have noted, regional governments have taken little action in response (Ilfiyah et al., 2015; Republika, 2014). This does not appear to have been because of a lack of technical capacity at the local level to manage teacher redistribution; in general, local educational agencies appear to have the required data and analytical capacity to redistribute teachers in a more efficient and effective way. ${ }^{6}$ Rather, the lack of action appears to have been in part because regional governments have not seen the threats contained in the regulation as credible and in part, because they have baulked at the political challenges that teacher redistribution entails. As noted above, teacher redistribution represents an attack on the interests of political and bureaucratic elites and teachers, both of whom have had significant capacity to push back against unwanted change. In the case of political and bureaucratic elites, this is because they have controlled the local state apparatus and its policy-making and implementation powers. In the case of teachers, it is because their electoral strength and political and social networks have given them the ability to effectively lobby local politicians, especially members of the DPRD and regional executives (i.e. the bupati or mayor). They have also, on occasion, been able to access the courts.

\section{THE POLITICAL ECONOMY OF TEACHER REDISTRIBUTION IN FOUR DISTRICTS}

Despite the serious political obstacles to teacher management reform, a small number of district/municipal governments have nevertheless introduced programs of teacher redistribution (Ilfiyah et al 2015; USAID Prioritas 2014). The introduction of these programs has not necessarily been a response to the Five Ministerial Decree nor

\footnotetext{
5 The term 'regional governments' refers here to provincial as well as district governments.

${ }^{6}$ Interviews with district and provincial education officials in the four districts discussed later in the paper, May-August 2015.
} 
motivated by technocratic/donor concerns. Where these programs have embodied such concerns, it has been because donors have been active within the region and played a crucial role in putting ideas on the table. The experiences of our four focus districts, all of which faced significant teacher distribution challenges (see Table One), illustrate the dynamics at work and the different outcomes that have prevailed at the regional level. I have disguised the identities of the districts/municipalities at the request of the funders of the research and to protect informants. The results reported are based on fieldwork carried out between May and August 2015.

\section{INSERT TABLE ONE HERE}

\section{Municipality A}

Municipality A is a major city and, as such, lacks remote and rural areas. But it still has significant distribution problems (see Table One). Several informants noted that the city has schools with too many teachers and others with too few, particularly with regards to subject teachers. ${ }^{7}$ Yet the city government has so far done little to address teacher distribution problems, notwithstanding the fact that under its mayor, who was elected in 2013, 'redistribution of quality' (pemerataan mutu) within the school system is a key plank of the local government's education policy agenda. The mayor has put in place some measures - such as the reintroduction of school catchment areas and caps on senior secondary school fees - aimed at achieving this objective. But he has so far failed to implement teacher redistribution.

The city government's initial response to the Five Ministerial Decree - made under the previous mayor - was to kick the problem downstairs. In a Circulating Letter (Surat Edaran) issued in July 2012, the then head of the local education agency instructed school principals to deal with the problem by coordinating among themselves. ${ }^{8}$ His replacement as head, who was appointed by the current mayor, appears to have more ownership of the problem. He has tried to produce local regulations providing for redistribution. But these have so far been held up in the legal section (bagian hukum) of the education agency. The problem, according to informed sources, has been that mid-level officials within the agency have been effectively sabotaging moves to rotate or redistribute teachers reflecting their interest in maintaining the patronage and political networks that link them to schools and, in particular, principals and teachers in 'favourite' schools most likely to lose from redistribution. ${ }^{9}$

\section{Municipality $B$}

Like Municipality A, Municipality B has significant teacher distribution problems despite lacking remote and rural areas (see Table One). Again, like Municipality A, these appear to center on the distribution of subject teachers..$^{10}$ Between 2008 and 2013, the regional government did little to address this problem, the mayor and his regional secretary taking the view that redistribution was unnecessary since the city had too many teachers. ${ }^{11}$ The city Education Board, an advisory body including a range of local education stakeholders, made a recommendation to the education agency at the time that it carry out a mapping of teacher needs and allocate teachers to schools accordingly. But this was never taken up. ${ }^{12}$ One branch head (kepala bagian) in the education agency official explained that the issue of teacher redistribution had been discussed extensively within the education agency but that there had so far been little willingness to tackle the problem in any systematic or serious way. Indeed, they had floated the idea of kicking the problem downstairs to community-level education agency branches (UPTD). He stated that the key obstacle was the political challenges involved in teacher redistribution. ${ }^{13}$

Since 2013, it appears that the city education agency has, however, started to change direction on the issue. 2013 saw two important developments. The first was the election of a new mayor although, because of a Constitutional Court challenge to the election result, he did not take up the job until late 2014. His choice as head of the local education agency told us that teacher redistribution is one of his top priorities indicating that the agency may be more active in this area in future. ${ }^{14}$ Having only been in the job for four months at the time of interview, however, he had not yet had the chance to make much progress so far.

\footnotetext{
${ }^{7}$ Interviews with the head of the Municipality A Education Agency, May 2015, and FAGI/FGII activist, May 2015.

${ }^{8}$ Title of the regulation withheld because it identifies the municipality.

${ }^{9}$ Interviews, Municipality A, May 2015.

${ }^{10}$ Interviews with the head of Municipality B Education Agency, and the Branch head for SMP, SMA and SMK Municipality B, August 2015.

${ }^{11}$ Interviews with former mayor of Municipality B and former head of the city education agency and currently (August 2015) Regional Secretary, Municipality B, August 2015.

${ }^{12}$ Interview with the head of the Education Board, Municipality B, August 2015.

${ }^{13}$ Interview, Municipality B, August 2015.

${ }^{14}$ Interview, Municipality B, August 2015
} 
The second development was the introduction of new and more demanding technical guidelines (juknis) for the professional allowance associated with the certification program. According to the head of the junior and senior secondary education branch in the education agency, the tighter requirements imposed by these guidelines raised the risk of a negative State Financial Audit Agency (BPK) or State Finance and Development Supervision Agency $(\mathrm{BPKP})^{15}$ audit finding if city claims regarding the number of teachers who are eligible for the professional allowance could not be fully substantiated. This in turn could trigger cuts to central government transfers to the city government. Beginning in 2013-2014, he has consequently carried out a detailed mapping of teacher needs in junior and senior secondary schools and been careful to ensure that teacher transfers were done in accordance with schools' genuine need for teachers. In contrast to the 5 Ministerial Decree, then, it would appear that, at least for this official, the new technical guidelines for the professional allowance combined with BPK/BPKP audit processes posed a credible threat to the city government even if the introduction of the new guidelines may not have been directly intended to affect teacher distribution.

\section{District A}

District $\mathrm{A}$ is a large district that includes urban and rural areas, some of which are remote. Like Municipality A and Municipality B, it has had significant teacher distribution problems, particularly at both primary and junior secondary level (Table One). In contrast to these municipalities, however, it has been relatively active in redistributing teachers as well as changing their type, level and/or function (jenis, jenjang, fungsi) ${ }^{16}$ for several years.

The local education agency began planning for teacher redistribution shortly after the central government issued Government Regulation 74/2008 on Teachers. This regulation established eligibility requirements for a professional allowance due to teachers through a new certification program, including that they teach face-to-face for at least 24 hours per week. The education agency carried out mapping (pemetaan) to establish areas of teacher shortage and excess from 2009 but it was not until 2012 that it actually began to redistribute teachers. Education agency figures show that, of 12,000 PNS teachers working in District A around this time, 454 were moved in 2012, 249 in 2013, 60 in 2014 and 129 in 2015. But the 2012 figure includes 251 who moved at their own initiative between 2009 and 2011, so the real 2012 figure should be $203 .{ }^{17}$ The increase between 2014 and 2015 was made necessary by the introduction of a new national curriculum in 2013 which eliminated some subjects from the curriculum. In the wake of the new curriculum, the education agency carried out a remapping of teacher supply and need to determine areas of shortage and excess. It then reassigned teachers to new types or levels and in some cases new schools so that they could meet the 24 -hour requirement. ${ }^{18}$

The key driving force of change in District A with regards to teacher redistribution has been a concern to help teachers meet the 24 hour and linearity ${ }^{19}$ requirements for receiving the professional allowance attached to the certification program rather than concerns related to budgetary efficiency or educational quality (although the latter have been recognized as potential payoffs). ${ }^{20}$ Change has not been donor-driven. USAID's Prioritas program, which operates in the district, only became operational there in 2013, well after the district government began to move on redistribution, although it has provided some legitimacy to the reforms by garnering international donor, education ministry and media attention (see, for instance, Jawa Pos 2014). ${ }^{21}$

The politics of redistributing teachers in District A had three discrete phases:

- $\quad$ The first phase entailed school supervisors (education agency officials who oversee school affairs) working out that many teachers in District A would be ineligible for the professional allowance unless the local government redistributed them to places and roles that enabled them to meet the requirements of Government Regulation No. 74 of 2008. They did this through discussions with school principals and teachers as part of their supervisory responsibilities, hearing complaints from teachers about being short of hours. They then made a recommendation for teacher redistribution to the head of the education

\footnotetext{
15 These agencies are respectively the state external and internal auditors.

${ }^{16}$ Change in type $=$ e.g. maths teacher becoming a science teacher; change in level=e.g. SMA maths teacher becoming an SMP maths teacher; change in function $=$ e.g. teacher moving into an administrative position.

${ }^{17}$ Interviews with senior education agency officials, District A, June 2015.

${ }^{18}$ Interviews with senior education agency officials, District A, June 2015.

19 To receive the professional allowance, teachers have to teach subjects that are related to their academic qualifications and field of certification-i.e. teachers with maths qualifications should be teaching maths. This is referred to as linearity (linearitas).

20 This came through particularly strongly in interviews with key actors within the education agency at the time. Their respective positions and roles are discussed in the main text.

${ }^{21}$ For a more general analysis of the way in which local elites exploit donor programs for political advantage, see Choi and Fukuoka (2014).
} 
agency's Civil Service sub-section (Kasubag Kepegawaian) through the School Supervisor Working Deliberative Group, a body bringing together the district's school supervisors. ${ }^{22}$

- The second phase entailed the head of the education agency's Civil Service sub-section working in conjunction with the head of the Civil Service Rotation Section (Kabid Mutasi Kepagawaian) at the Regional Civil Service and Training Agency (BKDD) to persuade the head of the education agency, the district head (bupati), the vice-bupati and other senior officials to sign off on a redistribution program. Parallel processes seem to have been going on in the local health agency with regards to civil servant health workers (and perhaps other agencies), so it is likely that officials in these agencies were involved as well. ${ }^{23}$ The result was the issuance of bupati regulation providing the legal foundation for teacher redistribution within District A as well as redistribution of other civil servants.

- $\quad$ The third phase entailed the local government engaging in change management - that is, ensuring that teacher redistribution occurred without provoking a destabilizing or politically damaging backlash from affected teachers. The key elements in this phase were threefold:

i) extensive and early socialization of the policy among teachers. This was carried out through school principals, the PGRI, and direct visits to schools by the then education agency head. In the latter case, the focus was on the opportunities presented by the certification program but the need for redistribution to enable teachers to meet certification requirements was also flagged.

ii) early engagement of the regional parliament (DPRD), particularly the commission responsible for education matters (Komisi 4), to ensure that it was on board.

iii) neutralization of protests by teachers who reacted negatively to proposed moves. It appears that a small number of teachers made individual protests about proposed moves through direct approaches to the education agency or the local parliament. One, a teacher with preman (street thug)-like tendencies, reportedly placed a gun on the table in his meeting with education agency officials, a clear form of intimidation. Education agency officials say that they successfully neutralized most protests by pointing out the benefits from proposed moves in terms of improving their eligibility for the certification program. If teachers continued to object, they were allowed to stay in their existing positions (although in these cases they did not receive the professional allowance if their teaching load remained below 24 hours or they did not meet the linearity requirements). ${ }^{24}$

The fact that teacher redistribution was so closely linked to the requirements of the certification program suggests that the principal motivations of the supervisors and the mid-level education agency officials who were so crucial in pushing the process forward and the senior officials who ultimately approved teacher redistribution were related to the dynamics of local patronage and political networks. As patrons within the system, they had a concern to ensure their clients at the school level received their due entitlements in order to consolidate political and patronage networks. As rent-seekers within the system, they also had a concern to maximize amount of the money within the school system that is available for potential appropriation.

\section{District B}

Like District A, District B is a large district that straddles urban and rural areas, some of which are remote; has had significant teacher distribution problems (see Table One); and has been relatively active in redistributing teachers. Indeed, of our four regional cases, it has been by far the most aggressive reformer in this respect. Since 2007-2008, the regional government has redistributed almost 3,000 civil servant teachers, accounting for a very large proportion of the teaching labor force. The numbers redistributed were: 644 in 2008, 0 in 2009, 344 in 2010 , 360 in 2011, 552 in 2012, 502 in 2013, 166 in 2014, and 331 in 2015. Some teachers who were transferred were moved to isolated parts of the district.

Importantly for our purposes, the first round of redistribution (2007-2008) happened just before the central government issued Government Regulation 74/2008 which made it compulsory for teachers to teach 24 hours face-to-face to be eligible for the professional allowance. In contrast to District A, then, redistribution does not appear to have been conceived from the outset as a way of ensuring that teachers receive the professional allowance. Rather technocratic concerns seem to have had a more significant influence reflecting two factors. The

\footnotetext{
${ }^{22}$ Interview with a school supervisor and education agency official, District A, June 2015.

${ }^{23}$ Interview with senior education agency officials, District A, June 2015.

${ }^{24}$ Interviews with senior education agency officials and a former head of the education agency, District A, June 2015
} 
first relates to the personal capacities of the district's bupati from 2005 to 2015. Several informants described the bupati as 'educated' and 'capable of thinking'. The second factor is his apparent political strategy of seeking legitimacy for his education policies by securing the support of international donors. Under his rule, District B became home to a wide range of donor education projects including Bermutu, Prodep, and a UNICEF project on school-based management. As I note below, this meant that local education officials had access to technocratic ideas and policy solutions concerning teacher distribution at a crucial moment.

The politics of teacher redistribution proceeded in eight main stages.

- First, the bupati was elected in 2005 on the basis of promises to transform District B into a 'Clever District' (Kabupaten Cerdas). Teacher redistribution was not explicitly part of this agenda at this point. His five-year development plan for 2005-2010 identified education as a priority sector but made no mention of teacher redistribution. ${ }^{25}$

- Second, the government of District B applied for and was selected to be part of a World Bank-MoEC pilot study on teacher management. This study dealt with, among other things, issues of teacher distribution (see World Bank and Department of National Education 2010). This introduced the regional government, in particular the education agency, to relevant technocratic ideas. ${ }^{26}$

- Third, recognizing that the bupati was open to ideas for reform-indeed, in all likelihood demanding them-education agency officials carried out a mapping of teacher distribution within the district and presented the results to him. ${ }^{27}$

- Fourth, education agency officials began to 'socialize' teacher redistribution among parliamentary representatives through working group meetings (rapat kerja) with members of the DPRD committee (Komisi 2) responsible for education. ${ }^{28}$

- $\quad$ Fifth, teacher redistribution was carried out in 2007-2008. This precipitated a lot of complaints, many of which were directed to the DPRD. According to the DPRD representative that we interviewed, the DPRD held firm, having agreed to the policy. ${ }^{29}$ The Bermutu project started in 2008-District B was one of the project's pilot regions. This project focused mainly on teacher training but also had a component related to the development of a teacher database.

- Sixth, teacher redistribution was subject to challenge in the local state administrative court (PTUN) around 2008-2009 (the dates are a little unclear). Only a small number of teachers were involved in the PTUN case (between 1 and 3 depending on the source of information). The case was expensive: for instance, it entailed flying in experts from Gadjah Mada University and elsewhere and hiring lawyers. This suggests that the teachers had financial support from other sources. Who backed the dissident teachers is unknown. However, several informants suggested that their motivation was to damage the bupati in the run-up to the 2010 district head and 2011 gubernatorial elections, so the backer may have been a rival politician or one of his supporters. In any event, they lost the PTUN case: the court found in favor of the government of District B.

- Seventh, the district government introduced an isolated areas allowance (tunjangan daerah terpencil) figuring that this would reduce resistance in the future.

- Eighth, the district government passed a regional regulation (perda) and series of bupati regulations (perbup) to provide a regulatory framework for teacher management and constrain future governments.

\section{Summary}

In sum, then, the four cases above illustrate that teacher redistribution has posed significant political challenges for regional governments, explaining why — in the context of no credible threat of sanctions from above-most regional governments have baulked at addressing teacher distribution problems. At the same time, however, they also illustrate that redistribution has been possible where:

- $\quad$ as in District A, mid-level government officials, especially ones at the local education agency, have judged that reform initiatives can be exploited for patronage purposes; secured support from above; and devised effective strategies for managing the politics of reform (by, for instance, securing the support of the DPRD and buying off the losers from reform);

- $\quad$ as in District B, reform-minded district leaders have been elected providing an imperative for education agency officials to design reform programs and they have had access to relevant ideas and policy advice; or

\footnotetext{
${ }^{25}$ Interviews with the current head of education agency in District B who was the head of the Basic Education branch in the mid-2000s, District B, July 2015; and the former rector of the local state university (former IKIP). District B, August 2015.

${ }^{26}$ I wish to thank Susi Iskandar for her advice on this point.

${ }^{27}$ Interview with the head of education agency in District B, July 2015.

${ }^{28}$ Interview with a member of Komisi 2, District B, July 2015.

${ }^{29}$ Interview with a member of Komisi 2, District B, July 2015.
} 
- $\quad$ as recently in Municipality B, the central government has devised and implemented policy instruments that, accidently or otherwise, provide regional governments with an incentive to carry out teacher redistribution;

\section{CONCLUSION}

Indonesia faces serious problems with regards to teacher distribution. This paper has sought, using a political economy framework, to explain the origins of this problem, identify the political obstacles to reform, and specify the political conditions under which the country has made progress in promoting such reform. In policy terms, the implication of the analysis is that promoting a more equitable distribution of teachers in Indonesia will require not only new policy frameworks and programs that are appropriate in a technical sense but also effective in addressing the political challenges involved. Broadly speaking, the findings suggest that there are two prospective strategies. The first is to reduce the ability of political and bureaucratic elites and the patronage and political networks they control, particularly ones at the regional level, to resist teacher redistribution by transferring authority over the implementation of teacher management policy to the central government. The second, which might come into play if recentralisation is politically impossible and considered unlikely to work for other reasons, involves a combination of three elements: i) a disciplinary component that seeks to alter the incentives faced by political and bureaucratic elites at the regional level with regards to teacher distribution by presenting regional governments with a credible threat that they will be punished if they do not implement teacher management reforms and/or a credible commitment that they will be rewarded if they do; ii) a working with the grain component that seeks to promote teacher distribution by exploiting opportunities presented by the certification program, in particular, the financial incentive it has created for teachers to move schools in order to meet certification requirements, to replace school principals, and carry out school mergers; and iii) a facilitative component that seeks to support redistribution in regions where the political preconditions for reform are already in place because the local leadership is supportive of reform.

\section{REFERENCES}

Al Samarrai, S. et al (2012) Making Better Use of Teachers: Strengthening Teacher Management to Improve the Efficiency and Equity of Public Spending, Jakarta: World Bank.

Bjork, C. (2003) 'Local Responses to Decentralization Policy in Indonesia', Comparative Education Review, 47 (2), 184-216.

Choi, I. and Fukuoka. Y. (2014) 'Co-opting Good Governance Reform: The Rise of Not-so-Reformist leader in Kebumen, Central Java’, Asian Journal of Political Science, 23 (1), 83-101.

Heyward, M., Hadiwijaya, A., Mahargianto, Priyono, E., (2017) 'Reforming Teacher Deployment in Indonesia', Journal of Development Effectiveness, 9 (2), 245-262.

Ilfiyah, A., Hendri F., Rasiki R., and Yudhistira, R. (2015) Kegagalan Pemerataan Guru: Evaluasi SKB 5 Menteri Tahun 2011 Tentang Penataan dan Pemerataan Guru PNS di Indonesia, Jakarta: ICW.

Irawan A., Eriyanto, L. Djani, and A. Sunaryanto (2004) Mendagangkan Sekolah, Jakarta: Indonesia Corruption Watch.

Jalal, F. and Musthafa, B. (eds.) (2001) Education Reform in the Context of Regional Autonomy: The Case of Indonesia, Jakarta: MoNE, Bappenas, and World Bank.

King, D. (1995/6) 'Bureaucracy and Implementation of Complex Tasks in Rapidly Developing States: Evidence From Indonesia', Studies in Comparative International Development, 30 (4), 78-92.

Kompas (1970) 'PGRI Bernaung Dibawah Sekber Golkar', 11 July.

Kompas (2010) 'SKB Redistribusi Guru Disiapkan', 9 June, available at: http://edukasi.kompas.com/read/2010/06/09/20065384/SKB.Redistribusi.Guru.Disiapkan, _ accessed 14 September 2015.

McLeod, R. (2000) ‘Soeharto’s Indonesia: A Better Class of Corruption', Agenda, 7 (2), 99-112. 
Mulkeen, A. (2010) Teachers in Anglophone Africa: Issues in Teacher Supply, Training, and Management, Washington DC: World Bank.

Pisani, E. (2013) ‘A Nation of Dunces?’ Inside Indonesia, 114 (Oct-Dec).

Prawiro, R. (1998) Indonesia's Struggle for Economic Development: Pragmatism in Action, Oxford: Oxford University Press.

Reeve, D. (1985) Golkar of Indonesia: An Alternative to the Party System, Singapore: Oxford University Press.

Republika (2014) 'Ini Kabupaten yang Berhasil Melakukan Pemerataan Guru', 20 October, available at: http://www.republika.co.id/berita/nasional/umum/14/10/20/ndpeob-ini-kabupaten-yang-berhasil-melakukanpemerataan-guru, accessed 21 September.

Rosser, A. and Joshi, A. (2013) 'From User Fees to Fee-Free: The Politics of Realising Universal Free Basic Education in Indonesia', Journal of Development Studies, 49 (2), 175-189.

Schiller, J. (1999) 'The 1997 Indonesian Elections: "Festival of Democracy” or "Costly Fiction"”, University of Victoria Occasional Paper No 22, May.

The Economist (2014) 'Schools In', 13 December.

USAID Prioritas (2015) Policy Brief: Teacher Deployment in Indonesia, Jakarta: USAID Prioritas.

Warta Ekonomi (2018) 'Mendikbud Berdalih Sistem Zonasi Demi Pemerataan Guru, Setuju?', https://www.wartaekonomi.co.id/read187867/mendikbud-berdalih-sistem-zonasi-demi-pemerataan-gurusetuju.html.

World Bank (1998) Education in Indonesia: From Crisis to Recovery, Washington DC: World Bank.

World Bank (2013) Spending More or Spending Better: Improving Education Financing in Indonesia, Jakarta: World Bank.

World Bank and Department of National Education (2010) Implementation Completion Report: Pilot Study: Teacher Employment and Deployment, Jakarta: Department of National Eduation. 


\section{Table on Case Studies}

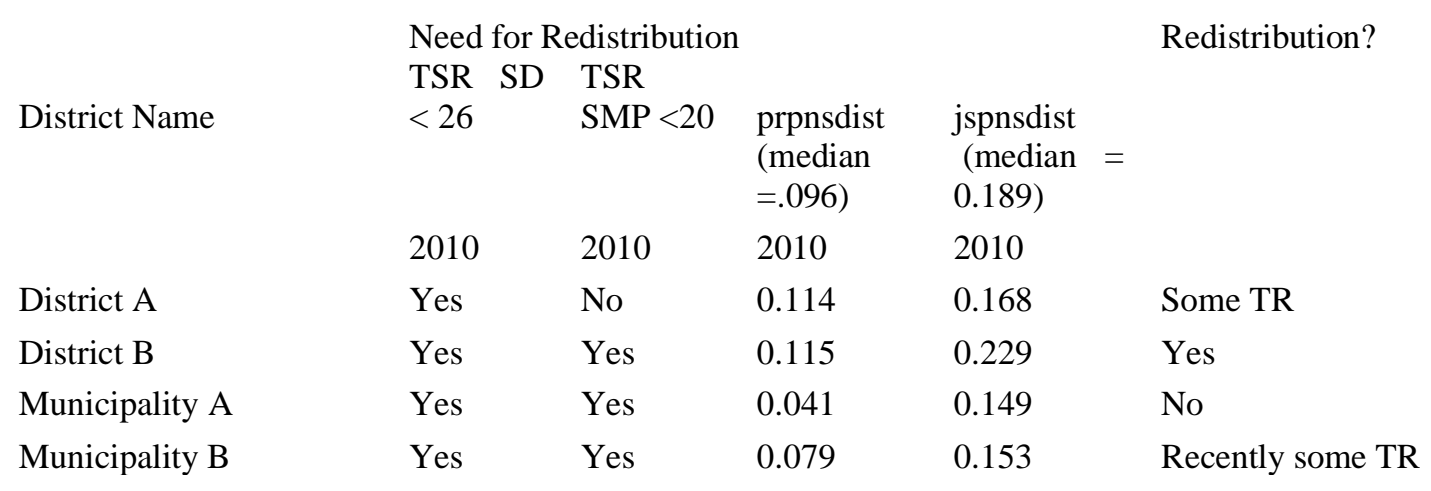

Notes: i) TSR = teacher student ratio; ii) TR = teacher redistribution; iii) prpnsdist and jspnsdist are measures of the extent to which civil servant teachers can be redistributed in a region at the primary and junior secondary levels respectively.

Source: World Bank, Jakarta. 


\section{University Library}

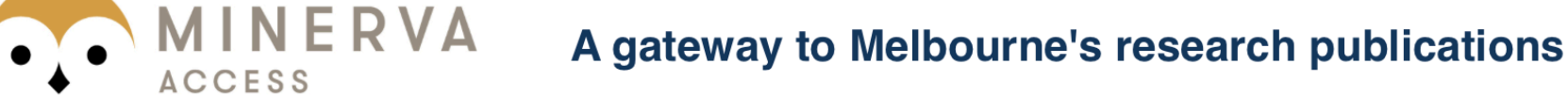

Minerva Access is the Institutional Repository of The University of Melbourne

Author/s:

Rosser, A

Title:

Governing Guru: The Political Economy of Teacher Distribution in Indonesia

Date:

2020-08-20

Citation:

Rosser, A. (2020). Governing Guru: The Political Economy of Teacher Distribution in Indonesia. Suryani, A (Ed.). Tirtowalujo, I (Ed.). Masalam, H (Ed.). Preparing Indonesian Youth A Review of Educational Research, (1), pp.48-65. Brill - Sense.

Persistent Link:

http://hdl.handle.net/11343/268124 